\title{
Corrigendum
}

\section{Dairy food intake of Australian children and adolescents 2-16 years of age: 2007 Australian National Children's Nutrition and Physical Activity Survey - Corrigendum}

Danielle L Baird, Julie Syrette, Gilly A Hendrie, Malcolm D Riley, Jane Bowen and Manny Noakes

First published online 9 August 2012

doi:10:1017/S1368980012001176, Published online by Cambridge University Press 15 May 2012

In the first sentence of the Acknowledgements,

instead of:

The analyses that formed the basis of this report were funded by CSIRO Food and Nutritional Sciences and Dairy Innovation Australia Limited (DIAL).

it should read:

The analyses that formed the basis of this report were funded by CSIRO Food and Nutritional Sciences and the Dairy Health and Nutrition Consortium (DHNC).

Elsewhere in this paragraph, the acronym DIAL should read DHNC.

\section{Reference}

Baird DL, Syrette J, Hendrie GA, Riley MD, Bowen J \& Noakes M (2012) Dairy food intake of Australian children and adolescents 2-16 years of age: 2007 Australian National Children's Nutrition and Physical Activity Survey. Public Health Nutrition, published online 15 May 2012, doi:10.1017/S1368980012001176. 